Check for updates

Cite this: RSC Adv., 2020, 10, 26928

Received 22nd May 2020

Accepted 14th July 2020

DOI: $10.1039 / \mathrm{dOra04556j}$

rsc.li/rsc-advances

\section{Onion-derived activated carbons with enhanced surface area for improved hydrogen storage and electrochemical energy application $\uparrow$}

\begin{abstract}
Nicholas M. Musyoka, (D) *a Bridget K. Mutuma (D)*b and Ncholu Manyala (D) *b
High surface area activated carbons (ACs) were prepared from a hydrochar derived from waste onion peels. The resulting $A C s$ had a unique graphene-like nanosheet morphology. The presence of $N(0.7 \%)$ and $O$ content $(8.1 \%)$ in the OPAC $-800{ }^{\circ} \mathrm{C}$ was indicative of in situ incorporation of nitrogen groups from the onion peels. The specific surface area and pore volume of the best OPAC sample was found to be 3150 $\mathrm{m}^{2} \mathrm{~g}^{-1}$ and $1.64 \mathrm{~cm}^{3} \mathrm{~g}^{-1}$, respectively. The hydrogen uptake of all the OPAC samples was established to be above 3 wt\% (at $77 \mathrm{~K}$ and 1 bar) with the highest being 3.67 wt $\%\left(800{ }^{\circ} \mathrm{C}\right.$ ). Additionally, the OPAC$800{ }^{\circ} \mathrm{C}$ achieved a specific capacitance of $169 \mathrm{~F} \mathrm{~g}^{-1}$ at a specific current of $0.5 \mathrm{~A} \mathrm{~g}^{-1}$ and retained a capacitance of $149 \mathrm{~F} \mathrm{~g}^{-1}$ at $5 \mathrm{~A} \mathrm{~g}^{-1}$ in a three electrode system using $3 \mathrm{M} \mathrm{KNO}_{3}$. A symmetric supercapacitor based on the OPAC $-800{ }^{\circ} \mathrm{C} / / \mathrm{OPAC}-800^{\circ} \mathrm{C}$ electrode provided a capacitance of $158 \mathrm{~F}$

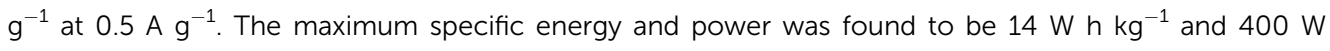
$\mathrm{kg}^{-1}$, respectively. Moreover, the device exhibited a high coulombic efficiency of $99.85 \%$ at $5 \mathrm{~A} \mathrm{~g}^{-1}$ after 10000 cycles. The results suggested that the high surface area graphene-like carbon nanostructures are excellent materials for enhanced hydrogen storage and supercapacitor applications.
\end{abstract}

\section{Introduction}

Carbon-based porous materials have widely been used for hydrogen storage as well as in electrochemical energy storage applications. Even though these materials can be derived from many different feedstocks, ${ }^{1,2}$ the use of biomass is often preferred because it is easily available, low cost and also renewable. $^{2-4}$ Examples of biomass that have been used to generate activated carbons (ACs) are such as tree bark, ${ }^{5}$ banana peel, ${ }^{6}$ algae, ${ }^{2}$ olive stones, ${ }^{7}$ among many others. The type of carbonaceous feedstock and the activation process play critical roles in determining the properties of the resulting ACs. ${ }^{3,8}$ For example, a recent study based on cellulose acetate-derived ACs with oxygen functional groups achieved a record-breaking hydrogen uptake value i.e. gravimetric capacity of $8.9 \mathrm{wt} \%$ at $-196{ }^{\circ} \mathrm{C}$ and 30 bar. $^{9}$ On the other hand, N-doped ACs have also received great interest in electrochemical energy storage applications since $\mathrm{N}$ presence leads to enhancement of the specific capacitance. ${ }^{10,11}$ The carbonization of $\mathrm{N}$-containing biomass is

${ }^{a}$ Centre for Nanostructures and Advanced Materials (CeNAM), Chemicals Cluster, Council for Scientific and Industrial Research (CSIR), Meiring Naude Road, Pretoria, 0001, South Africa. E-mail: nmusyoka@csir.co.za; Tel: +27-12-841-4806

${ }^{b}$ Department of Physics, Institute of Applied Materials, SARCHI Chair in Carbon Technology and Materials, University of Pretoria, South Africa. E-mail: bridgetmutuma@gmail.com; Ncholu.manyala@up.ac.za

† Electronic supplementary information (ESI) available. See DOI: 10.1039/d0ra04556j also found to be cheaper and presents a straightforward approach for obtaining N-doped carbons devoid of using nitrogen-containing chemical precursors.

Owing to the need to identify a carbon precursor with high concentrations of oxygen and nitrogen functional groups, waste onion peels were considered as an attractive feedstock. In this case, onions (Allium cepa L.) are known to contain high oxygen functionalities due to the flavour precursors such as $(+)-S$ alk(en)yl cysteine sulphoxides (CSOs), trans-S-1-propenyl cysteine sulphoxide (PeCSO) and $S$-propyl cysteine sulphoxide (PCSO). ${ }^{12}$ The lachrymatory effect of onions is caused by presence of volatile propanthial $S$-oxide. ${ }^{13}$ A study by Venkateswarlu et al. ${ }^{14}$ confirmed that oxygen richness of carbonised onion peel aided As(III) adsorption from contaminated water. On the other hand, the presence of $\mathrm{N}$ and $\mathrm{S}$ functionalities in ACs have also been reported to enhance hydrogen storage. ${ }^{15-17}$ Even though there are some studies that have reported the use of onion to derive ACs, these studies either used discarded green onion leaves ${ }^{\mathbf{1 8}}$ or used un-optimised activation procedures ${ }^{\mathbf{1 9}}$ which masked their true potential. Concerning the use of green onion leaves versus onion bulb scales, a study conducted by Lancaster et al. ${ }^{20}$ reported that the flavour precursors moves from the leaf blades towards the bulb scales which means that the concentration of oxygen-rich functionalities are often higher in onion bulb scales than in the leaves.

The abundance of onion skin waste, as a valorisable resource, can be evidenced by the availability of more than 500000 metric tons which is discarded every year within the 
European Union. ${ }^{21}$ The utilisation of the discarded outer papery protective layers of onions in the production of ACs not only has the advantage of alleviating their disposal challenge but could lead to high properties of resulting ACs for enhanced hydrogen storage capacities. The nitrogen in the ACs would also enable better electrochemical capacitance owing to the increase in surface wettability and carbon hydrophilicity in aqueous electrolytes.

Herein, we report on the utilization of onion peels as the carbonaceous feedstock and $\mathrm{KOH}$ as the activating agent to produce nanosheet-like porous carbons. The effect of activation temperature on the structural and textural properties of the onion peel derived activated carbons (OPAC) was investigated. The obtained ACs exhibited a high specific surface area (2241$\left.3150 \mathrm{~m}^{2} \mathrm{~g}^{-1}\right)$ and an attractive pore volume $\left(0.94-1.64 \mathrm{~cm}^{3} \mathrm{~g}^{-1}\right)$. The OPAC material obtained at $800{ }^{\circ} \mathrm{C}$ (OPAC- $800{ }^{\circ} \mathrm{C}$ ) had the highest hydrogen uptake capacity of $3.67 \mathrm{wt} \%$ at 1 bar and $77 \mathrm{~K}$. When used as the electrode material for supercapacitors in $3 \mathrm{M}$ $\mathrm{KNO}_{3}$, the OPAC- $800{ }^{\circ} \mathrm{C}$ achieved a specific capacitance of $169 \mathrm{~F}$ $\mathrm{g}^{-1}$ at $0.5 \mathrm{~A} \mathrm{~g}^{-1}$ in a three-electrode system. A fabricated symmetric device using the OPAC- $800{ }^{\circ} \mathrm{C}$ displayed a capacitance of $158 \mathrm{~F} \mathrm{~g}^{-1}$ with corresponding specific energy and power of $14 \mathrm{~W} \mathrm{~h} \mathrm{~kg}^{-1}$ and $400 \mathrm{~W} \mathrm{~kg}^{-1}$ at $0.5 \mathrm{~A} \mathrm{~g}^{-1}$.

\section{Experimental}

\subsection{Starting materials}

Potassium hydroxide, $\mathrm{KOH}$ (85\%, Merck), argon, Ar (99.99\%, Afrox) and hydrochloric acid, $\mathrm{HCl}$ (37\%, Merck) were used during the preparation of the onion derived ACs.

\subsection{Preparation of the onion hydrochar}

In this work, red onion skin wastes (peels) were collected, washed to remove excess dirt and then dried at $60{ }^{\circ} \mathrm{C}$ for $12 \mathrm{~h}$. Thereafter, the onion-based hydrochar was obtained via hydrothermal carbonization which involved the heating of an aqueous mixture of the onion waste $\left(300 \mathrm{~g} \mathrm{~L}^{-1}\right)$ in an autoclave at $200{ }^{\circ} \mathrm{C}$ for $4 \mathrm{~h}$. The resulting hydrochar was recovered by filtration, washed several times using deionised water and thereafter dried at $90{ }^{\circ} \mathrm{C}$ for $12 \mathrm{~h}$.

\subsection{Activation of the onion hydrochar}

Pre-carbonization of the onion hydrochar was performed at $500{ }^{\circ} \mathrm{C}$ for $1 \mathrm{~h}$ under argon atmosphere with a ramp rate of $5{ }^{\circ} \mathrm{C} \min ^{-1}$. The pre-carbonized hydrochar was then mixed thoroughly with $\mathrm{KOH}$ at a mass ratio of $1: 4$ (hydrochar : $\mathrm{KOH}$ ) and a few drops of water added to form a slurry which was then allowed to dry at $70^{\circ} \mathrm{C}$ for $12 \mathrm{~h}$. The mixture was then heated up to a pre-activation temperature of $400{ }^{\circ} \mathrm{C}$ for $30 \mathrm{~min}$ and then to an activation temperature of $600{ }^{\circ} \mathrm{C}$ for $1 \mathrm{~h}$ in a chemical vapour deposition reactor. The product was mixed with $10 \mathrm{wt} \% \mathrm{HCl}$ for $24 \mathrm{~h}$ followed by washing with deionised water to a neutral $\mathrm{pH}$ and thereafter dried in an oven at $100{ }^{\circ} \mathrm{C}$ for $12 \mathrm{~h}$ to give the AC denoted as OPACs $-600{ }^{\circ} \mathrm{C}$. A similar procedure was used at activation temperatures of $700{ }^{\circ} \mathrm{C}$ and $800{ }^{\circ} \mathrm{C}$ to produce OPACs$700{ }^{\circ} \mathrm{C}$ and OPACs- $800{ }^{\circ} \mathrm{C}$, respectively.

\subsection{Characterization}

2.4.1 General characterization and hydrogen storage testing. The ACs morphology was determined using a Zeiss Ultra Plus 55 field emission scanning electron microscope (FESEM) and a JEOL JEM-2100F transmission electron microscope operated at working voltage of $2 \mathrm{kV}$ and $200 \mathrm{kV}$, respectively. The degree of graphitization of the ACs was investigated using a T64000 micro-Raman spectrometer (532 nm laser excitation wavelength and power of $5 \mathrm{~mW}$ ). A PANalytical X'Pert Pro powder diffractometer was used for X-ray diffraction analysis. A Mettler, Toledo, TGA/SDTA 851e instrument was used for thermogravimetric analysis (TGA) which was conducted upto $\sim 1000{ }^{\circ} \mathrm{C}$ at a ramping rate of $10^{\circ} \mathrm{C} \mathrm{min}^{-1}$ under a mixture of

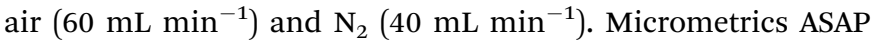
$2020 \mathrm{HD}$ analyser was used for $\mathrm{N}_{2}$ and $\mathrm{H}_{2}$ sorption measurements at liquid $\mathrm{N}_{2}$ temperature $(77 \mathrm{~K}$ ) and up to 1 bar. The samples were firstly degassed for $8 \mathrm{~h}$ at $200{ }^{\circ} \mathrm{C}$, under vacuum conductions (down to $10^{-7}$ bar), to remove any traces of adsorbed water and/or other physisorbed gases. X-ray photoelectron spectroscopy (XPS) analysis was conducted using a Physical Electronics Quantum 2000 and the data analysed using the CasaXPS software.

2.4.2 Electrochemical characterization of the electrode materials. The onion-derived activated carbon electrode material, acetylene carbon black and polyvinylidene fluoride (PVDF) were mixed following a mass ratio of $80: 10: 10$ and made into a slurry by adding a few drops of $N$-methyl-2-pyrrolidone (NMP). The resulting mixture was then coated onto a $1 \mathrm{~cm}^{2}$ nickel foam and dried under vacuum at $80{ }^{\circ} \mathrm{C}$ for $6 \mathrm{~h}$. Electrochemical measurements were conducted using the Bio-Logic VMP300 potentiostat (Knoxville TN 37930, USA). Varying scan rates were employed during the collection of cyclic voltammetry (CV) data. Also, different specific current values were used for galvanostatic charge-discharge (GCD) measurements. A frequency range of $10 \mathrm{mHz}$ to $100 \mathrm{kHz}$ was used during the electrochemical impedance spectroscopy (EIS) measurements. A threeelectrode conformation that consisted of the as-prepared OPAC material (as working electrode), glassy carbon counter electrode and $\mathrm{Ag} / \mathrm{AgCl}$ reference electrode was assembled for electrochemical measurements in a $3 \mathrm{M} \mathrm{KNO}_{3}$ electrolyte solution. A coin cell configuration employing a Whatman separator and $3 \mathrm{M} \mathrm{KNO}_{3}$ was used for a symmetric device. The discharge curve of the GCD plot was used to calculate the specific capacitance for a half cell using eqn (1) whereas eqn (2) was used for the symmetric device. The specific energy and specific power of the device was determined using eqn (3) and (4).

$$
\begin{gathered}
C_{\mathrm{s}}=\frac{I \Delta t}{\Delta V m} \mathrm{~F} \mathrm{~g}^{-1} \\
C_{\mathrm{el}}=\frac{4 I \Delta t}{\Delta V m} \mathrm{~F} \mathrm{~g} \mathrm{~g}^{-1} \\
E_{\mathrm{s}}=\frac{C_{\mathrm{el}}(\Delta V)^{2}}{28.8} \mathrm{~W} \mathrm{~h} \mathrm{~kg}^{-1} \\
P_{\mathrm{s}}=\frac{3600 E_{\mathrm{s}}}{\Delta t} \mathrm{~W} \mathrm{~kg} \mathrm{~kg}^{-1}
\end{gathered}
$$


where $m$ depicts the total mass of the electrode material, $I$ is the current applied, $\Delta t$ being the discharge duration, $C_{\mathrm{el}}$ is the specific capacitance of a single electrode, and $\Delta V$ refers to the device voltage window.

\section{Results and discussion}

\subsection{Morphological and structural analysis}

Fig. 1 presents morphological characteristics (SEM images) of the OPACs at high and low magnifications. The OPACs- $600{ }^{\circ} \mathrm{C}$ and OPACs-700 ${ }^{\circ} \mathrm{C}$ displayed wrinkled carbon morphology (Fig. 1a and b). In contrast, the OPACs- $800{ }^{\circ} \mathrm{C}$ exhibited a nanosheet-like morphology (Fig. 1c). The formation of the sheet-like structures at higher temperature could due to the exfoliation of staked onion cells after the intercalation of $\mathrm{K}$. TEM images of the OPAC samples generated at $600{ }^{\circ} \mathrm{C}$ and $700{ }^{\circ} \mathrm{C}$ also shows the presence of overlapped wrinkled carbon nanostructures (Fig. 1d and e) whereas the OPAC-800 ${ }^{\circ} \mathrm{C}$ displayed transparent sheets with thinner walls (Fig. 1f). The observed crumpled nanosheet-like morphology of the OPAC samples can be correlated to the onion peels sheet-like structures. This observation reinforces the postulation that the structure of the raw material as well as the activation conditions plays an important role in determining the morphology of the resulting AC materials. In a different study, Venkateswarlu and his coworkers ${ }^{\mathbf{1 4}}$ reported the generation of graphene-oxide like $2 \mathrm{D}$ carbon sheets after the pyrolysis of waste onion sheaths at $700{ }^{\circ} \mathrm{C}$ for $2 \mathrm{~h}$ in $\mathrm{N}_{2}$. Since the peels were obtained from mature onions, Turnbull et al. ${ }^{22}$ had earlier reported that the bulb cells of mature onions are often larger and thin walled. Therefore, we can postulate that upon the pre-carbonization of the onion hydrochar, the carbon wall tends to expand and this process can be accelerated by the expulsion of carbon dioxide during the activation step to lead to the creation of the observed nanosheets that resembles graphene sheets.

Fig. 2 shows the Raman spectra of OPACs with D peaks observed at 1340-1344 $\mathrm{cm}^{-1}$ characteristic of the breathing mode of $\mathrm{sp}^{2}$ carbon atoms as well as the presence of $\mathrm{sp}^{3}$
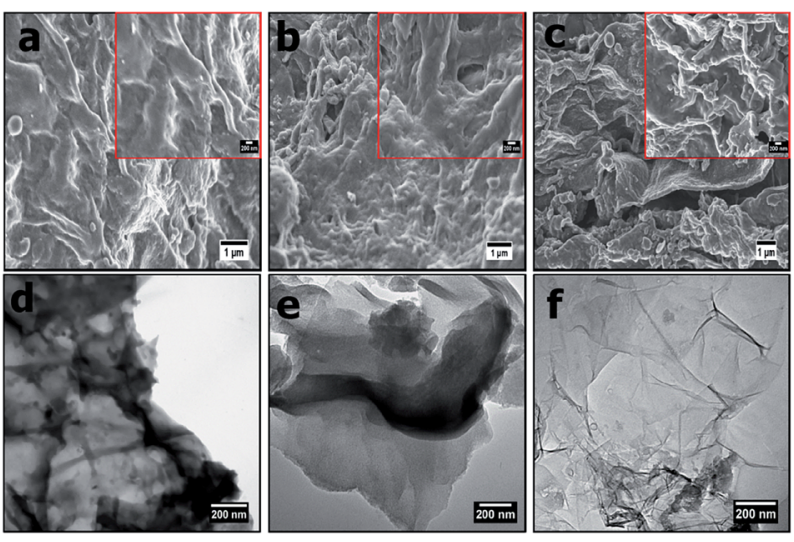

Fig. 1 SEM images of (a) OPAC $-600^{\circ} \mathrm{C}$, (b) OPAC $-700^{\circ} \mathrm{C}$, (c) OPAC$800^{\circ} \mathrm{C}$ taken at low magnification (insets shows the images at high magnification) and $(d-f)$ their respective TEM images.

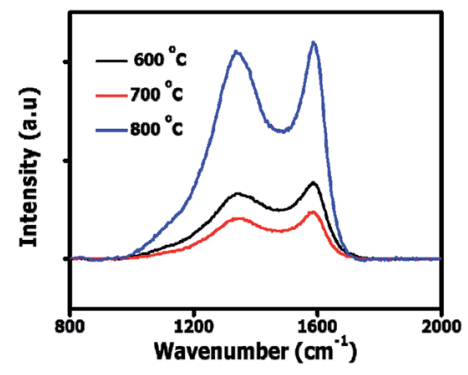

Fig. 2 The Raman spectra of the onion-derived ACs.

hybridized amorphous carbon domains within the AC structure. ${ }^{23,24}$ A G peak attributed to the Raman active $E_{2 g}$ in-plane vibration mode of $\mathrm{sp}^{2}$ atoms in graphite was observed at $1586 \mathrm{~cm}^{-1} .^{25}$

The upshift in the $\mathrm{D}$ band position as well as the observed increase in $I_{\mathrm{D}} / I_{\mathrm{G}}$ ratios relative to the activation temperature can be ascribed to the creation of more defects within the carbon matrix (Table 1). Besides, the Raman data shows that at $800{ }^{\circ} \mathrm{C}$ more amorphous domains were present in the ACs resulting in the high $I_{\mathrm{D}} / I_{\mathrm{G}}$ ratio displayed. Fig. $\mathrm{S} 1 \dagger$ illustrates the XRD patterns of the OPAC samples. The presence of a broad hump coupled with the absence of a sharp peak depict the amorphous nature of sample. A weak broad diffraction peak at $2 \theta \sim 43^{\circ}$ was observed in the OPAC 600 and $700{ }^{\circ} \mathrm{C}$ samples, characteristic of (100) diffraction plane of graphite structure. ${ }^{26}$ However, for the OPAC $800{ }^{\circ} \mathrm{C}$ sample, this peak is barely visible and implies that graphitization decreased with the increase in the activation temperature. This observation correlates well with the Raman analysis presented in Table 1 . Besides, in all the samples, the absence of the (002) diffraction plane of graphite peak at $2 \theta \sim$ $24^{\circ}$ was noted. This could suggest that a possible rearrangement of the structure and the creation of layer structure defects occurred due to $\mathrm{K}$ intercalation into the carbon structure. ${ }^{27,28}$ Fig. S2 $\uparrow$ present the TGA plots of the OPAC samples. The decomposition of the OPAC $600{ }^{\circ} \mathrm{C}$ started slightly below $400{ }^{\circ} \mathrm{C}$ whereas that of the OPAC $700{ }^{\circ} \mathrm{C}$ and $800{ }^{\circ} \mathrm{C}$ were at relatively higher temperature values.

\subsection{Textural analysis}

The $\mathrm{N}_{2}$ sorption isotherms of the three ACs generated from the three temperature variations are presented in Fig. 3. The sample generated at $600{ }^{\circ} \mathrm{C}$ exhibited a type I isotherm whereas those produced at $700{ }^{\circ} \mathrm{C}$ and $800{ }^{\circ} \mathrm{C}$ displayed both type I and IV

Table 1 Comparative $D$ and $G$ band positions together with $I_{D} / I_{G}$ ratio of the onion-derived ACs

\begin{tabular}{llll}
\hline Material & $\begin{array}{l}\mathrm{D} \text { band position } \\
\left(\mathrm{cm}^{-1}\right)\end{array}$ & $\begin{array}{l}\mathrm{G} \text { band position } \\
\left(\mathrm{cm}^{-1}\right)\end{array}$ & $I_{\mathrm{D}} / I_{\mathrm{G}}$ ratio \\
\hline OPAC-600 ${ }^{\circ} \mathrm{C}$ & 1340 & 1586 & 0.86 \\
OPAC-700 ${ }^{\circ} \mathrm{C}$ & 1342 & 1586 & 0.87 \\
OPAC-800 ${ }^{\circ} \mathrm{C}$ & 1344 & 1586 & 0.96
\end{tabular}




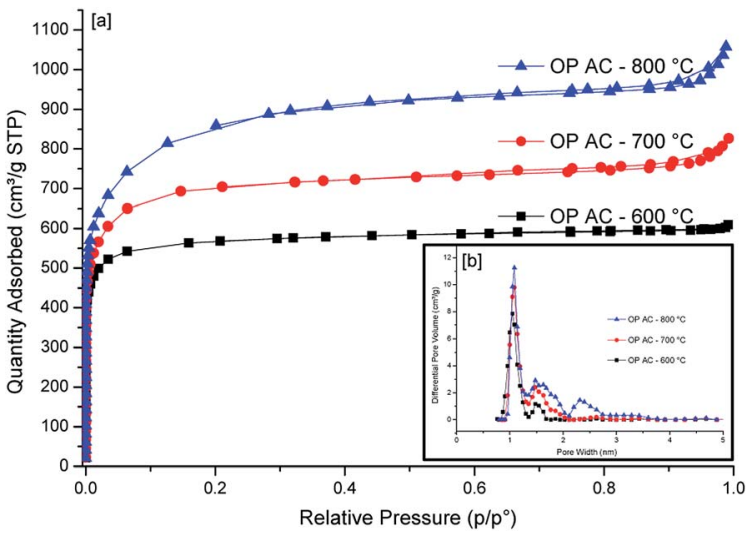

Fig. $3 \mathrm{~N}_{2}$ sorption isotherms (a) together with pore side distribution curves (b) of OPACs produced at 600,700 and $800{ }^{\circ} \mathrm{C}$.

isotherms. Type I isotherm is indicative of a microporous material having pores that are less than $2 \mathrm{~nm}$ while type IV isotherms depicts the presence of both micropores and mesopores. ${ }^{29}$ The sharp gas uptake in all the samples at low partial pressure region is a confirmation that most of the exposed surface resides mostly inside the micropores. This observation is further confirmed by the pore size distribution curves presented in Fig. 3b (inset). In this case, the samples produced at $600{ }^{\circ} \mathrm{C}$ and $700{ }^{\circ} \mathrm{C}$ portrayed a bimodal pore size distribution with the main pores having dimensions which are less than $2 \mathrm{~nm}$ (i.e. 1.05 and $1.08 \mathrm{~nm}$, respectively). However, OPAC $800{ }^{\circ} \mathrm{C}$ sample exhibited a trimodal pore size distribution having pores positioned at 1.08, 1.48 and $2.31 \mathrm{~nm}$. The presence of pores above $2 \mathrm{~nm}$ is an indication of the presence of mesopores which is further corroborated by the occurrence of the slight hysteresis loop in the isotherm.

The surface areas of the obtained ACs are presented in Table 2 . The highest values were obtained for the sample generated at $800{ }^{\circ} \mathrm{C}\left(3150 \mathrm{~m}^{2} \mathrm{~g}^{-1}\right)$ whereas the samples from $600{ }^{\circ} \mathrm{C}$ and $700{ }^{\circ} \mathrm{C}$ activation temperatures had $2706 \mathrm{~m}^{2} \mathrm{~g}^{-1}$ and $2241 \mathrm{~m}^{2}$ $\mathrm{g}^{-1}$, respectively. The temperature-dependent increase in the surface area can be attributed to the creation of more pores at higher temperatures. Typically, the $\mathrm{KOH}$ reacts with the carbon during the activation process to give $\mathrm{K}_{2} \mathrm{CO}_{3}$ and metallic $\mathrm{K}$ which intercalates into the carbon matrix. ${ }^{30}$ The $\mathrm{K}_{2} \mathrm{CO}_{3}$ then reacts with carbon resulting in a partial etching of carbon atoms, emission of $\mathrm{CO}$ gas and the intercalation of more $\mathrm{K}$ thus, creating additional pores on the carbon surface at higher activation temperatures $\left(700^{\circ} \mathrm{C}\right.$ and $\left.800{ }^{\circ} \mathrm{C}\right)$. Finally, the removal of the intercalated potassium by the washing of the final product with HCL increases the porosity of the carbon nanosheet. The unprecedented high surface areas are exceptional for biomassderived carbons considering that the activating agent used was the conventional $\mathrm{KOH}$ without the inclusion of other special activation procedures. When compactivation strategy was applied by Mokaya's group, ${ }^{31}$ the compaction approach lead to ACs with 25\% higher specific surface area. It is believed that the unexpected high specific surface areas obtained in our case could be due to the nature of the obtained morphological features that had sheet-like surface structures. Almost similar morphological features were obtained when activation of glucose was done using potassium oxalate. ${ }^{3}$ However, the specific surface areas were found to be relatively lower (1270$1690 \mathrm{~m}^{2} \mathrm{~g}^{-1}$ ) compared to our current study except in the case when a mixture of melamine and potassium oxalate was utilised. From Table 2, it was noted that the proportion of micropore area relative to the total surface area for all samples was over $97 \%$ with the OPAC- $600{ }^{\circ} \mathrm{C}$ sample having the greatest proportion at $99.06 \%$. On the higher hand, the trend observed for the temperature-dependent surface area was also noted for the pore volumes with the highest being for the OPAC- $800{ }^{\circ} \mathrm{C}$ sample. It was also noted that the micropore volume represented $\geq 84 \%$ of the overall pore volume for the OPAC 700 and $800{ }^{\circ} \mathrm{C}$ activated samples with the highest being the low temperature activated carbon $\left(600{ }^{\circ} \mathrm{C}\right)$ which was at $\geq 94 \%$.

\subsection{Elemental composition by XPS analysis}

The elemental composition of the OPAC-800 ${ }^{\circ} \mathrm{C}$ sample was determined using X-ray photoelectron spectroscopy. The integral areas of the deconvoluted $\mathrm{C} 1 \mathrm{~s}, \mathrm{O} 1 \mathrm{~s}$ and $\mathrm{N}$ 1s peaks were used to calculate the atomic percentages present in the material. After pre-carbonization and $\mathrm{KOH}$ activation at $800{ }^{\circ} \mathrm{C}$, the oxygen, carbon and nitrogen contents were 8.1 at $\%, 91.2$ at $\%$ and 0.7 at $\%$, respectively. The low nitrogen content can be ascribed to the loss of nitrogenous products at the high activation temperature. ${ }^{32}$ Fig. 4 a shows the deconvoluted $\mathrm{C} 1 \mathrm{~s}$ peaks namely; $\mathrm{sp}^{2} \mathrm{C}=\mathrm{C}(283.7 ; 69.7 \%), \mathrm{sp}^{3} \mathrm{C}-\mathrm{C} / \mathrm{C}-\mathrm{N}(284.3 \mathrm{eV} ; 25.8 \%)$ and $\mathrm{C}=\mathrm{O}$ bonds $(285.5 ; 4.5 \%)$, respectively. ${ }^{33,34}$ The higher percentage of the $\mathrm{sp}^{2}$-hybridized carbons as compared to the $\mathrm{sp}^{3}$ carbon can be ascribed to the restoration of the graphitic carbons within the AC matrix at the high activation temperature $\left(800{ }^{\circ} \mathrm{C}\right)$. From Fig. $4 \mathrm{~b}$, the deconvoluted $\mathrm{O}$ 1s spectrum presented peaks centered at $530.9 \mathrm{eV}(\mathrm{O}-\mathrm{C}=\mathrm{O}), 532 \mathrm{eV}(\mathrm{O}-\mathrm{C})$ and $533.5 \mathrm{eV}(\mathrm{O}-\mathrm{C}-\mathrm{O})$. Fig. 4c displays the deconvoluted $\mathrm{N}$ 1s for the OPAC-800 ${ }^{\circ} \mathrm{C}$ sample with spectrum peaks centered at 398.3 (24.8\%), 399.7 (55.7\%), 400.6 (17.9\%) and 402.1 (1.6\%) which corresponds to the pyridinic, pyrrolic, graphitic $\mathrm{N}$ atoms and

Table 2 Textural properties of OPACs produced at 600,700 and $800{ }^{\circ} \mathrm{C}$

\begin{tabular}{lllll}
\hline Sample & $\begin{array}{l}\text { BET surface } \\
\text { area }\left(\mathrm{m}^{2} \mathrm{~g}^{-1}\right)\end{array}$ & $\begin{array}{l}\text { Micropore area } \\
\left(\mathrm{m}^{2} \mathrm{~g}^{-1}\right)\end{array}$ & $\begin{array}{l}\text { Total pore vol. } \\
\left(\mathrm{cm}^{3} \mathrm{~g}^{-1}\right)\end{array}$ & $\begin{array}{l}\text { Micropore vol. } \\
\left(\mathrm{cm}^{3} \mathrm{~g}^{-1}\right)\end{array}$ \\
\hline & & & & $\begin{array}{l}\mathrm{H}_{2} \text { uptake } \\
(\mathrm{wt} \%)\end{array}$ \\
OPAC-800 ${ }^{\circ} \mathrm{C}$ & 3150 & 3080 & 1.64 & 1.39 \\
OPAC-700 ${ }^{\circ} \mathrm{C}$ & 2706 & 2651 & 1.28 & 1.10 \\
OPAC-600 ${ }^{\circ} \mathrm{C}$ & 2241 & 2220 & 0.94 & 0.89
\end{tabular}



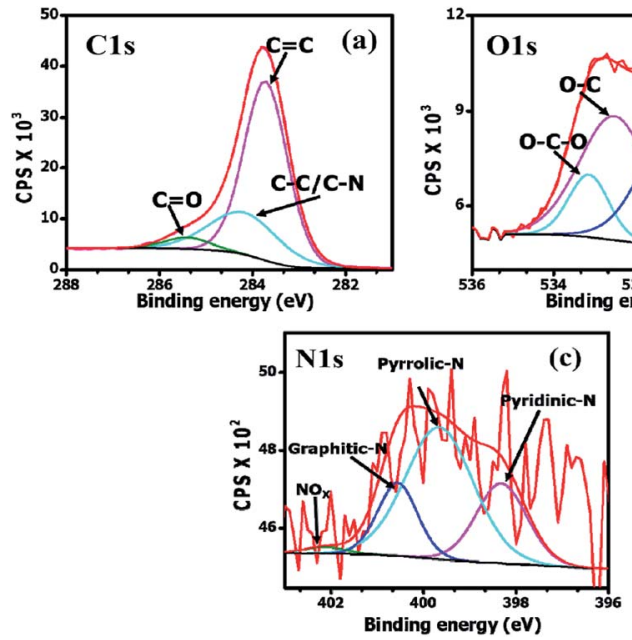

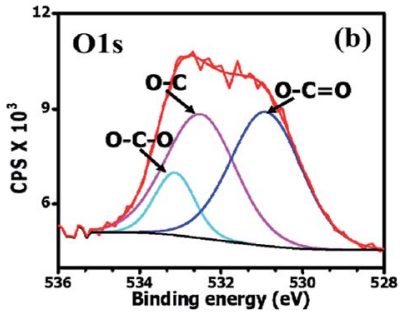

(c) the oxidized pyridinic- $\mathrm{N}$, respectively. ${ }^{35,36}$ The presence of pyridinic-N and pyrrolic- $\mathrm{N}$ is known to readily promote carbon surface wettability, which consequently enhances the electrochemical capacitive properties. ${ }^{35,37,38}$

\subsection{Hydrogen uptake}

The hydrogen sorption isotherms are presented in Fig. 5. All the three samples had a $\mathrm{H}_{2}$ uptake that was above $3 \mathrm{wt} \%$ at $77 \mathrm{~K}$ and 1 bar (as also shown in Table 2). The lack of a hysteresis loop in the isotherms meant that the $\mathrm{H}_{2}$ uptake was reversible. Noteworthy, no saturation was attained at the analysis pressure which is an indication that higher $\mathrm{H}_{2}$ sorption capacities would be expected at higher pressure ranges. The impressive hydrogen uptake at 1 bar (3.08-3.67 wt\%) was comparatively higher than values often reported for typical porous carbons which are usually within the range of $2-3 \mathrm{wt} \%{ }^{9}{ }^{9}$ Most importantly, the best hydrogen uptake value of $3.67 \mathrm{wt} \%$ up to 1 bar at $77 \mathrm{~K}$ obtained using the onion peels derived activated carbons is superior to

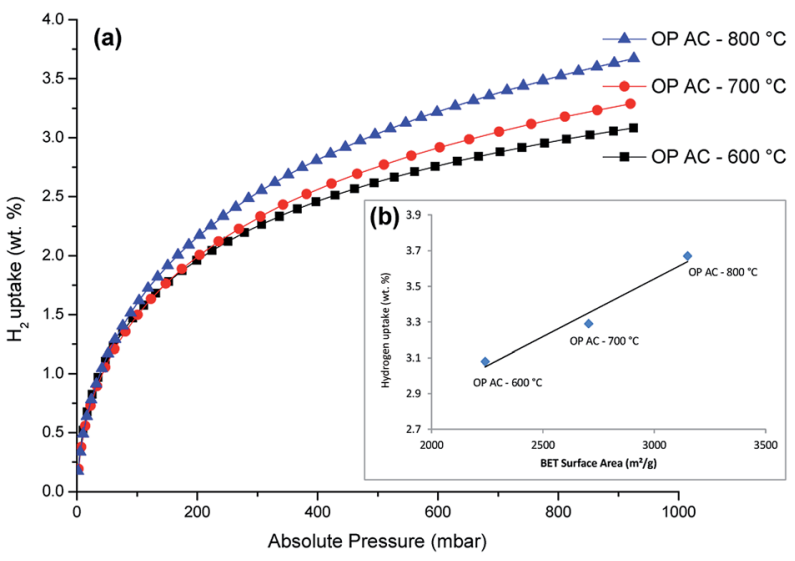

Fig. $5 \mathrm{H}_{2}$ sorption isotherms of OPACs produced at 600,700 and $800^{\circ} \mathrm{C}$ (a) and the respective relationship of $\mathrm{H}_{2}$ uptake with the surface areas (inset, (b)). most reported data for other related materials ${ }^{28,39-44}$, as listed in Table 3. The abundance of narrow pores (nano and micro levels) in a porous material has been reported to make the biggest contribution to $\mathrm{H}_{2}$ adsorption capacity ${ }^{45-48}$ and hence the observed enhancements of the performance of the activated carbon in this study.

As shown in Fig. 5b, a linear correlation of the specific surface area with the hydrogen uptake capacity for the OPAC samples was also observed in this study. This observation is in agreement with Chahine's rule which highlights the generally accepted direct proportionality trend of increasing $\mathrm{H}_{2}$ gravimetric capacity with increasing surface area commonly observed in nanoporous materials. ${ }^{49}$ It is also thought that the presence of oxygen functionality (as confirmed by XPS) could have also played a role in the observed high $\mathrm{H}_{2}$ adsorption capacity. In this regard, an earlier study by Blankenship II et al. ${ }^{9}$ had reported that a combined effect of high surface area, oxygen-rich functionality and high microporosity contributed to the enhancement of gravimetric hydrogen storage capacity. The researchers further alluded that the oxygen beneficial effect is more pronounced at low pressure ( $\sim 1$ bar) region owing to the fact that the interaction between the hydrogen and the material surface is more intimate when compared to the higher pressure ranges where hydrogen uptake is most likely to happen by space filling mechanisms. Even though high $\mathrm{H}_{2}$ uptake values are often reported for analyses conducted at cryogenic temperatures, doping the sorbent materials with heteroatoms or inclusion of metal particles (such as Pt) can enhance hydrogen storage capacities at room temperature..$^{50}$ These strategies could be applied to the OPACs materials obtained in this study.

\subsection{Electrochemical performance}

The evaluation of electrochemical performance of the assynthesized OPAC electrode materials was based on a threeelectrode configuration using a $3 \mathrm{M} \mathrm{KNO}_{3}$ electrolyte solution. Fig. 6a presents the cyclic voltammograms of all the electrode materials taken at $40 \mathrm{mV} \mathrm{s}^{-1}$. The operating cell potential of $0.8 \mathrm{~V}$ was chosen as no overpotential peak as observed in Fig. S3a $\uparrow$ for both negative and positive potential. For the 3 samples, a quasi-rectangular CV curve was observed indicating a typical electrical double layer capacitor (EDLC) property. ${ }^{51}$ However, the CV curve for the OPAC- $600{ }^{\circ} \mathrm{C}$ was slightly distorted suggesting that the material has more oxygenated functional groups. ${ }^{52}$ Fig. $6 \mathrm{~b}$ displays the quasi-symmetrical galvanostatic charge-discharge plots obtained at $1 \mathrm{~A} \mathrm{~g}^{-1}$ specific current in an operating cell potential of 0.0 to $0.8 \mathrm{~V}$. The calculated specific capacitance values at $1 \mathrm{~A} \mathrm{~g}^{-1}$ were 61,67 and $77 \mathrm{~F} \mathrm{~g}^{-1}$ for the OPAC- $600{ }^{\circ} \mathrm{C}$, OPAC- $700{ }^{\circ} \mathrm{C}$ and OPAC- $800{ }^{\circ} \mathrm{C}$, respectively. It was found that the OPAC- $800{ }^{\circ} \mathrm{C}$ gave the highest current response as well as the longest discharge time when compared to the others. From Fig. 6c, it was evident that there was a direct correlation of specific capacitance and activation temperature with the highest capacitance recorded for OPAC$800{ }^{\circ} \mathrm{C}$ sample. This observation can be attributed to the sample's improved pore volume and high specific surface area. The electrochemical responses of the as-prepared electrode 
materials were also examined in the negative potential range of -0.8 to $0.0 \mathrm{~V}$ in $3 \mathrm{M} \mathrm{KNO}_{3}$. Fig. $\mathrm{S} 3 \mathrm{~b}-\mathrm{d} \dagger$ shows the $\mathrm{CV}$ curves, GCD plots and specific capacitance versus specific current displaying a similar trend to what was observed in the positive potential range. From Fig. S3d, $\uparrow$ the respective specific capacitance values for the OPAC- $600{ }^{\circ} \mathrm{C}$, OPAC-700 ${ }^{\circ} \mathrm{C}$ and OPAC$800{ }^{\circ} \mathrm{C}$ samples were found to be 120,146 and $157 \mathrm{~F} \mathrm{~g}^{-1}$ when measured at a specific current value of $1 \mathrm{~A} \mathrm{~g}^{-1}$. The higher specific capacitance of the OPAC- $800{ }^{\circ} \mathrm{C}$ can be ascribed to its higher surface area that provided better electrolyte ion accessibility to the pores within the carbon matrix. Good rate capability was observed for all the electrode materials.

The impedance properties of the OPAC materials at an operating frequency of $10 \mathrm{mHz}$ to $100 \mathrm{kHz}$ (Fig. 6d) was studies using electrochemical impedance spectroscopy (EIS) technique. The OPAC- $800{ }^{\circ} \mathrm{C}$ displayed the shortest diffusion length indicating faster ion diffusion within the material. The OPAC- $600{ }^{\circ} \mathrm{C}$ curve was found to deviate slightly from the vertical axis depicting a less capacitive behaviour as compared to its counterparts. The intersection of curves with the horizontal axis describes the equivalent series resistance (ESR) which is a sum total of the active materials intrinsic resistance, electrolyte resistance, and the contact resistance occurring between the electrode materials and the current collector. ${ }^{53-55}$ The ESR was measured to be $0.90,0.91$ and $1.14 \Omega$ for OPAC- $600{ }^{\circ} \mathrm{C}$, OPAC$700{ }^{\circ} \mathrm{C}$ and OPAC-800 ${ }^{\circ} \mathrm{C}$, respectively. The OPAC-600 ${ }^{\circ} \mathrm{C}$ depicted a large semicircle with a charge transfer resistance value of $1.02 \Omega$. In contrast, the OPAC- $800{ }^{\circ} \mathrm{C}$ had the smallest semicircle corresponding to a charge transfer resistance value of $0.03 \Omega$ and the shortest diffusion length, which are responsible for the improved electrochemical performance.

Fig. 7a and b present $\mathrm{CV}$ curves of OPAC- $800{ }^{\circ} \mathrm{C}$ sample that were obtained at various scan rates (10 to $\left.100 \mathrm{mV} \mathrm{s}^{-1}\right)$ both in the negative and positive operating potentials, ranging from -0.8 to $0 \mathrm{~V}$ and 0 to $0.8 \mathrm{~V}$, respectively. The figures show that the materials could operate well even within a reversible potential range. (a)

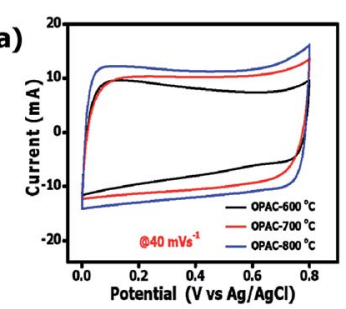

(c)

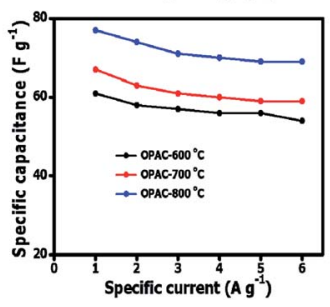

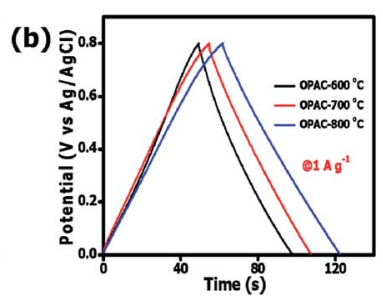

(d)

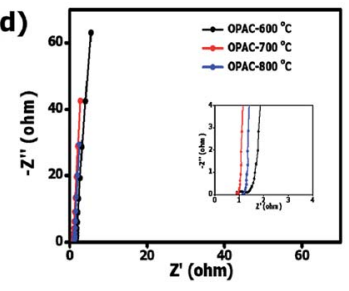

Fig. 6 (a) CV curves, (b) GCD curves, (c) plots of specific capacitance as a function of specific current and (d) Nyquist impedance plots of all the OPAC materials in a $3 \mathrm{M} \mathrm{KNO}_{3}$ electrolyte solution. 
A quasi-rectangular shape had been maintained even at higher scan rates of $100 \mathrm{mV} \mathrm{s}^{-1}$ depicting the fast ion diffusion kinetics on the reversal of potential. ${ }^{56}$ Fig. $7 \mathrm{c}$ and $\mathrm{d}$ show the GCD plots for the OPAC-800 ${ }^{\circ} \mathrm{C}$ tested at different specific current values of $0.5 \mathrm{~A} \mathrm{~g}^{-1}$ to $6 \mathrm{~A} \mathrm{~g}^{-1}$ in $3 \mathrm{M} \mathrm{KNO}_{3}$ electrolyte solution. The calculated specific capacitance values were 169 , $157,151,150,149$ and $149 \mathrm{~F} \mathrm{~g}^{-1}$ at $0.5,1,2,3,4$ and $5 \mathrm{~A} \mathrm{~g}^{-1}$ in the potential range of -0.8 to $0.0 \mathrm{~V}$. This shows that a good rate capability of $88 \%$ was maintained at higher specific current of $5 \mathrm{~A} \mathrm{~g}^{-1}$. At positive potential ranges of 0.0 to $0.8 \mathrm{~V}$, the specific capacitance values were $83,77,74,71,70$ and $69 \mathrm{~F} \mathrm{~g}^{-1}$ at $0.5,1$, 2, 3, 4 and $5 \mathrm{~A} \mathrm{~g}^{-1}$, respectively. It is observed that the OPAC$800{ }^{\circ} \mathrm{C}$ showed good rate capability at the distinct specific currents. As a result of the significant stability of the OPAC$800{ }^{\circ} \mathrm{C}$ electrode material, an assembly of a symmetric supercapacitor was deemed worthwhile.

A two-electrode setup in $3 \mathrm{M} \mathrm{KNO}_{3}$ electrolyte was used to investigate the electrochemical performance of the symmetric device because of the inherent potential that was exhibited from the half-cell analysis. Fig. 8a shows the CV curves of symmetric OPAC $800{ }^{\circ} \mathrm{C} / / \mathrm{OPAC} 800{ }^{\circ} \mathrm{C}$ device conducted at varying scan rates of between 10 and $100 \mathrm{mV} \mathrm{s}^{-1}$. The associated GCD profiles of the full device at various specific current are presented in Fig. 8b. The obtained GCD curves as well as the CV curves were found to be fairly symmetrical and rectangular, respectively, which is in accordance to the EDLC nature of activated carbon symmetric devices. ${ }^{57}$ The Nyquist plot for the symmetric device with an equivalent series resistance of $0.44 \Omega$ and a charge transfer resistance of $0.31 \Omega$ is presented in Fig. 8b. The ESR value was smaller compared to that reported for similar activated carbon. ${ }^{58,59}$ Fig. $8 \mathrm{~d}$ shows the specific capacitance of the symmetric SC that was plotted against the gravimetric specific current. The symmetric device was found to produce a maximum specific capacitance of $158 \mathrm{~F} \mathrm{~g}^{-1}$ at a specific current of $0.5 \mathrm{~A} \mathrm{~g}^{-1}$. Fig. 8e illustrates a Ragone plot for both specific energy and specific power of the symmetric device which are quite significant in the application of supercapacitors in real-life situations. At a specific current of (a)

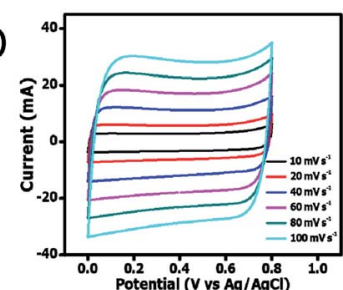

(c)

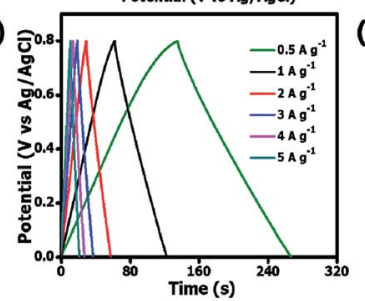

(b)

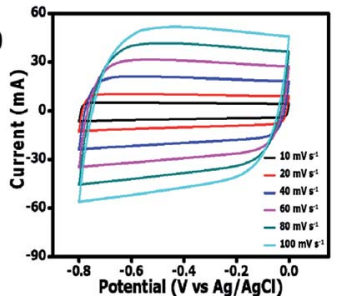

(d)

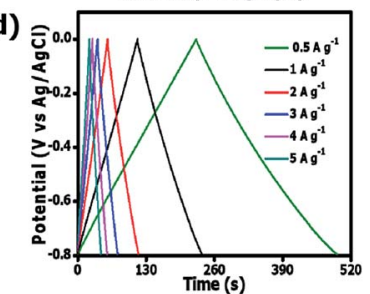

Fig. $7 \mathrm{CV}$ curves $(\mathrm{a}, \mathrm{b})$ and $\mathrm{GCD}$ plots $(\mathrm{c}, \mathrm{d})$ of the OPAC $-800{ }^{\circ} \mathrm{C}$ at a potential range of $-0.8 \mathrm{~V}$ to $0.8 \mathrm{~V}$ in $3 \mathrm{M} \mathrm{KNO}_{3}$ electrolyte.
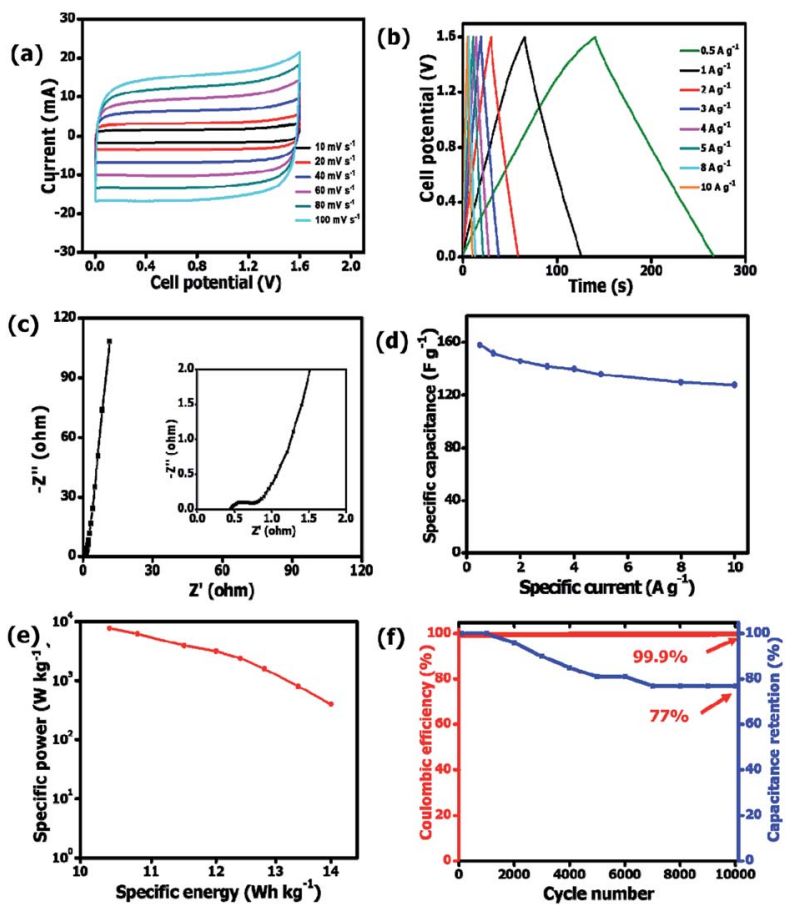

Fig. 8 CV curves at distinct scan rates, (b) GCD plots at various specific currents, (c) specific capacitance determined at various specific currents, (d) Nyquist impedance plots, (e) Ragone plot and (f) cycle stability and associated capacitance retention for the OPAC $800{ }^{\circ} \mathrm{C} / /$ OPAC $800^{\circ} \mathrm{C}$ symmetric device.

$0.5 \mathrm{~A} \mathrm{~g}^{-1}$, specific energy of $14.0 \mathrm{~W} \mathrm{~h} \mathrm{~kg}^{-1}$ corresponding to specific power of $400 \mathrm{~W} \mathrm{~kg}^{-1}$ was achieved. While at a specific current of $1 \mathrm{~A} \mathrm{~g}^{-1}$, a specific energy of $13.4 \mathrm{~W} \mathrm{~h} \mathrm{~kg}^{-1}$ corresponding to a specific energy of $800 \mathrm{~W} \mathrm{~kg}^{-1}$ was obtained. At $10 \mathrm{~A} \mathrm{~g}^{-1}$, specific energy of $10.4 \mathrm{~W} \mathrm{~h} \mathrm{~kg}^{-1}$ and corresponding specific power of $7655 \mathrm{~W} \mathrm{~kg}^{-1}$ was maintained. The symmetric device exhibited a coulombic efficiency of $99.9 \%$ and conserved $77 \%$ of the initial capacitance after 10000 charge and discharge cycles at a specific current of $5 \mathrm{~A} \mathrm{~g}^{-1}$ (Fig. 8f). This can be ascribed to the high specific surface area as well as the interconnected porous network of the OPAC- $800{ }^{\circ} \mathrm{C}$.

Table 3 shows that the OPAC $800{ }^{\circ} \mathrm{C}$ device presented not only good specific capacitance and excellent capacitance retention $(99.9 \%$ ) but also exhibited good specific energy, which was comparable to other related materials in literature. ${ }^{\mathbf{4 3 , 4 4 , 6 0 - 6 4}}$ From Table 3, the high specific capacitance for the OPAC- $800{ }^{\circ} \mathrm{C}$ electrode material obtained in this study is due to its high specific surface area, enhanced pore volume as well as the high $I_{\mathrm{D}} / I_{\mathrm{G}}$ ratios. These properties allows easy access of the electrolyte ions into the pores and enables better surface wettability. Moreover, the presence of trimodal pores in the nanosheet framework created an interconnected pore network for good energy storage. Finally, the oxygen and nitrogen functionalities play a crucial role in the influencing the hydrophilicity of the electrode surface which consequently impacts on its electrochemical performance. These results show the potential for the use of onion-peels and skins as a suitable biomass source in the 
generation of activated carbon nanosheets for application in hydrogen storage and electrochemical capacitors.

\section{Conclusions}

This study showed that activated carbons prepared from waste onion sheaths using $\mathrm{KOH}$, as the activating reagent, exhibited exceptional properties that made them desirable for hydrogen storage and electrochemical applications. The resulting ACs were found to have a nano-sheet type of morphology and had a moderate concentration of nitrogen and oxygen functional groups. The highest specific surface area $\left(3150 \mathrm{~m}^{2} \mathrm{~g}^{-1}\right)$ and pore volume $\left(1.64 \mathrm{~cm}^{3} \mathrm{~g}^{-1}\right)$ was achieved when activation was conducted at $800{ }^{\circ} \mathrm{C}$. Noteworthy, hydrogen sorption (at $77 \mathrm{~K}$ and 1 bar) for the 3 activated samples was above $3 \mathrm{wt} \%$ with the highest being $3.67 \mathrm{wt} \%$ when activation was conducted at $800{ }^{\circ} \mathrm{C}$. These values were comparatively higher than those often reported for typical porous carbons which usually range from 2 to $3 \mathrm{wt} \%$. Furthermore, the obtained ACs samples also exhibited commendable electrochemical performance, by having a specific capacitance of $158 \mathrm{~F} \mathrm{~g}^{-1}$ (at a specific current of $0.5 \mathrm{~A} \mathrm{~g}^{-1}$ ), specific energy of $14 \mathrm{~W} \mathrm{~h} \mathrm{~kg}^{-1}$, power of $400 \mathrm{~W}$ $\mathrm{kg}^{-1}$ and with a capacitance retention of $77 \%$ at $5 \mathrm{~A} \mathrm{~g}^{-1}$ even after 10000 charge-discharge cycles. The results demonstrated that the onion derived ACs could be considered as promising candidates for hydrogen storage and electrochemical energy storage applications.

\section{Conflicts of interest}

There are no conflicts of interest to declare.

\section{Acknowledgements}

The authors acknowledge financial support from the South Africa's National Research Foundation (NRF) for supporting South Africa/France collaboration project (Project No. CNMH20X) as well as the South African Research Chairs Initiative (SARChI) of the Department of Science and Innovation and the National Research Foundation (Grant No. 61056). Any opinions, findings and/or recommendations expressed in this study are those of the authors and not of the funding bodies.

\section{References}

1 Z. Heidarinejad, M. H. Dehghani, M. Heidari, G. Javedan, I. Ali and M. Sillanpää, Environ. Chem. Lett., 2020, 1-23.

2 B. Zhu, B. Liu, C. Qu, H. Zhang, W. Guo and Z. Liang, J. Mater. Chem. A, 2018, 6, 1523-1530.

3 M. Sevilla, A. S. M. Al-Jumialy, A. B. Fuertes and R. Mokaya, ACS Appl. Mater. Interfaces, 2018, 10, 1623-1633.

4 W. Sangchoom, D. A. Walsh and R. Mokaya, J. Mater. Chem. A, 2018, 6, 18701-18711.

5 D. Momodu, M. Madito, F. Barzegar, A. Bello, A. Khaleed, O. Olaniyan and N. manyala, J. Solid State Electrochem., 2017, 21, 859-872.
6 O. Fasakin, J. K. Dangbegnon, D. Y. Momodu, M. J. Madito, K. O. Oyedotun, M. A. Eleruja and N. Manyala, Electrochim. Acta, 2018, 262, 187-196.

7 J. Saleem, U. B. Shahid, M. Hijab, H. Mackey and G. McKay, Biomass Convers. Biorefin., 2019, 9, 775-802.

8 A. Jain, R. Balasubramanian and M. P. Srinivasan, Chem. Eng. J., 2016, 283, 789-805.

9 T. S. Blankenship II, N. Balahmar and R. Mokaya, Nat. Commun., 2017, 8, 1545.

10 K. Wang, N. Zhao, S. Lei, R. Yan, X. Tian and J. Wang, Electrochim. Acta, 2015, 166, 1-11.

11 X. Chen, J. Zhang, B. Zhang, S. Dong, X. Guo and X. Mu, Sci. Rep., 2017, 7, 7362.

12 M. G. Jones, J. Hughes, A. Tregova, J. Milne, A. B. Tomsett and H. A. Collin, J. Exp. Bot., 2004, 55, 1903-1918.

13 M. H. Brodnitz and J. V. Pascale, J. Agric. Food Chem., 1971, 19, 269-272.

14 S. Venkateswarlu, D. Lee and M. Yoon, ACS Appl. Mater. Interfaces, 2016, 8, 23876-23885.

15 Y. Xia, G. S. Walker, D. M. Grant and R. Mokaya, J. Am. Chem. Soc., 2009, 131, 16493-16499.

16 Y. Xia, Y. Zhu and Y. Tang, Carbon, 2012, 50, 5543-5555.

17 M. Zheng, H. Zhang, Y. Xiao, H. Dong, Y. Liu and R. Xu, Mater. Lett., 2013, 109, 279-282.

18 J. Yu, L. Gao, X. Li, C. Wu, L. Gao and C. Li, N. Carbon Mater., 2016, 31, 475-484.

19 A. Anitha and P. Kalyani, Int. J. Curr. Res., 2014, 6, 8433-8438. 20 J. E. Lancaster, B. J. McCallion and M. L. Shaw, Physiol. Plant., 1986, 66, 293-297.

21 I. S. Choi, E. J. Cho, J.-H. Moon and H.-J. Bae, Food Chem., 2015, 188, 537-542.

22 A. Turnbull, I. Galpin, J. Smith and H. Collin, New Phytol., 1981, 87, 257-268.

23 A. Burke, J. Power Sources, 2009, 91, 37-50.

24 P. Simon and Y. Gogotsi, Materials for electrochemical capacitors, in Nanosci. Technol., co-published with Macmillan Publishers Ltd, UK, 2009, pp. 320-329.

25 L. L. Zhang and X. S. Zhao, Chem. Soc. Rev., 2009, 38, 2520. 26 C. N. R. Rao, K. Biswas, K. S. Subrahmanyam and A. Govindaraj, J. Mater. Chem., 2009, 19, 2457-2469.

27 L.-Y. Meng and S.-J. Park, J. Colloid Interface Sci., 2010, 352, 498-503.

28 Y.-J. Heo and S.-J. Park, J. Ind. Eng. Chem., 2015, 31, 330-334. 29 K. S. W. Sing, D. H. Everett, R. A. W. Haul, L. Moscou, R. A. PierottI and J. Rouquerol, Pure Appl. Chem., 1985, 57, 603-619.

30 J. Wang and S. Kaskel, J. Mater. Chem. A, 2012, 22, 2371023725.

31 N. Balahmar, A. C. Mitchell and R. Mokaya, Adv. Energy Mater., 2015, 5, 1500867.

32 D. Hulicova, J. Yamashita, Y. Soneda, H. Hatori and M. Kodama, Chem. Mater., 2005, 17, 1241-1247.

33 J. Díaz, G. Paolicelli, S. Ferrer and F. Comin, Phys. Rev. B: Condens. Matter Mater. Phys., 1996, 54, 8064-8069.

34 B. K. Mutuma, B. J. Matsoso, K. Ranganathan, J. M. Keartland, D. Wamwangi and N. J. Coville, RSC Adv., 2017, 7, 21187-21195. 
35 D. Hulicova-Jurcakova, M. Seredych, G. Q. Lu and T. J. Bandosz, Adv. Funct. Mater., 2009, 19, 438-447.

36 S. Gao, Y. Chen, H. Fan, X. Wei, C. Hu and H. Luo, J. Mater. Chem. A, 2014, 2, 3317.

37 G. Lota, B. Grzyb, H. Machnikowska, J. Machnikowski and E. Frackowiak, Chem. Phys. Lett., 2005, 404, 53-58.

38 T. Kwon, H. Nishihara, H. Itoi, Q. Yang and T. Kyotani, Langmuir, 2009, 25, 11961-11968.

39 R. Yang, G. Liu, M. Li, J. Zhang and X. Hao, Microporous Mesoporous Mater., 2012, 158, 108-116.

40 C. Robertson and R. Mokaya, Microporous Mesoporous Mater., 2013, 179, 151-156.

41 C. Zhang, Z. Geng, M. Cai, J. Zhang, X. Liu and H. Xin, Int. J. Hydrogen Energy, 2013, 38, 9243-9250.

42 S. H. Arshad, N. Ngadi, A. A. Aziz, N. S. Amin, M. Jusoh and S. Wong, J. Energy Storage, 2016, 8, 257-261.

43 W. Hu, J. Huang, P. Yu, M. Zheng, Y. Xiao and H. Dong, ACS Sustainable Chem. Eng., 2019, 7, 15385-15393.

44 T. Chen, Y. Zhou, L. Luo, X. Wu, Z. Li and M. Fan, Electrochim. Acta, 2019, 325, 134941.

45 H. Nishihara and T. Kyotani, Adv. Mater., 2012, 24, 44734498.

46 Z. Yang, Y. Xia and R. Mokaya, J. Am. Chem. Soc., 2007, 129, 1673-1679.

47 K. M. Thomas, Catal. Today, 2007, 120, 389-398.

48 N. Alam and R. Mokaya, Energy Environ. Sci., 2010, 3, 17731781.

49 D. P. Broom, C. J. Webb, G. S. Fanourgakis, G. E. Froudakis, P. N. Trikalitis and M. Hirscher, Int. J. Hydrogen Energy, 2019, 44, 7768-7779.

50 J. M. Juárez, M. B. Costa and O. A. Anunziata, Int. J. Energy Res., 2015, 39, 128-139.
51 K. Fic, G. Lota, M. Meller and E. Frackowiak, Energy Environ. Sci., 2012, 5, 5842-5850.

52 K. Le Van and T. T. Luong Thi, Prog. Nat. Sci.: Mater. Int., 2014, 24, 191-198.

53 R. Kötz and M. Carlen, Electrochim. Acta, 2000, 45, 24832498.

54 B.-A. Mei, O. Munteshari, J. Lau, B. Dunn and L. Pilon, J. Phys. Chem. C, 2018, 122, 194-206.

55 J. Gamby, P. Taberna, P. Simon, J. F. Fauvarque and M. Chesneau, J. Power Sources, 2001, 101, 109-116.

56 J. Zhou, T. Zhu, W. Xing, Z. Li, H. Shen and S. Zhuo, Electrochim. Acta, 2015, 160, 152-159.

57 C. L. Liu, W. S. Dong, G. P. Cao, J. R. Song, L. Liu and Y. S. Yang, J. Electroanal. Chem., 2007, 611, 225-231.

58 Y. Show and K. Imaizumi, Diamond Relat. Mater., 2006, 15, 2086-2089.

59 D. Momodu, A. Bello, K. Oyedotun, F. Ochai-Ejeh, J. Dangbegnon, M. Madito and N. Manyala, RSC Adv., 2017, 7, 37286-37295.

60 L. Wang, G. Mu, C. Tian, L. Sun, W. Zhou and P. Yu, ChemSusChem, 2013, 6, 880-889.

61 J. Xu, Q. Gao, Y. Zhang, Y. Tan, W. Tian and L. Zhu, Sci. Rep., $2014,4,5545$.

62 P. Cheng, S. Gao, P. Zang, X. Yang, Y. Bai and H. Xu, Carbon, 2015, 93, 315-324.

63 T. Wei, X. Wei, L. Yang, H. Xiao, Y. Gao and H. Li, J. Power Sources, 2016, 331, 373-381.

64 F. O. Ochai-Ejeh, D. Y. Momodu, M. J. Madito, A. A. Khaleed, K. O. Oyedotun, S. C. Ray and N. Manyala, AIP Adv., 2018, 8, 055208.

65 I. Wróbel-Iwaniec, N. Díez and G. Gryglewicz, Int. J. Hydrogen Energy, 2015, 40, 5788-5796. 